\title{
METODE PENDIDIKAN YANG EFEKTIF BAGI ANAK DIDIK MENURUT AL QUR'AN: ANALISIS AYAT-AYAT AL QUR'AN
}

\author{
Muhammad Rijaal Qurrota A'yuni \\ SMP MUTIARA BUNDA, Bandung, 40416 \\ Pascasarjana UIN Sunan Gunung Djati Bandung \\ Email: muhammadrijaal003@gmail.com
}

\begin{abstract}
A great responsibility to educate a child lies in the obligation of an educator, both responsibilities that relate to faith or morals, intellectual as well as physical, mental and social. How delightful the parents and other educators can be when they can reap good results in the future as a result of their efforts. But is it enough for the educator to assume these responsibilities and carry out all of his obligations? After that, he considers himself to be loose in carrying out his duties. Or should he pay attention to methods in educating and continuing to seek perfection in educating? The answer is already certain that a good educator will always look for methods and means of education that are very influential in the formation of faith and morals of students

Keywords:

Protege, Effective, Method, Education
\end{abstract}

\begin{abstract}
Abstrak :Tanggung jawab yang besar untuk mendidik seorang anak terdapat pada kewajiban seorang pendidik, baik tanggung jawab yang berhubugan dengan keimanan maupun akhlak, intelektual maupun fisik, mental maupun sosial. Betapa gembiranya para orang tua dan pendidik lainnya ketika mereka dapat memetik hasil yang baik di masa depan sebagai buah dari usaha mereka. Namun apakah cukup bagi pendidik untuk mengemban berbagai tanggung jawab tersebut dan melaksanakan semua kewajibannya? Setelah itu, ia menganggap dirinya telah lepas beban dalam melaksanakan tugasnya. Ataukah ia harus memperhatikan metode dalam mendidik dan terus mencari kesempurnaan dalam mendidik? Jawabannya sudah dapat dipastikan bahwa seorang pendidik yang baik akan selalu mencari metode dan sarana pendidikan yang sangat berpengaruh dalam pembentukan akidah dan akhlak anak didik.

Kata kunci:

Anak didik, Efektif, Metode, Pendidikan
\end{abstract}

\section{PENDAHULUAN}

Pengetahuan tentang hakikat kedudukan manusia di alam semesta ini merupakan hal yang esensial. Karena manusia ditunjuk langsung oleh Allah untuk menjadi khalifah di muka bumi ini. Karena kedudukan itulah manusia harus memiliki pengetahuan yang luas. Pengetahuan dapat dimiliki dengan dua cara, melalui pendidikan formal dan pengalaman.

Dalam dunia pendidikan, manusia tidak hanya sebagai objek, tetapi juga subjek pendidikan, oleh karena itu pendekatan untuk menyampaikan pengetahuan tersebut harus dilakukan secara benar. Rasulullah SAW sebagai panutan telah memberikan contoh kepada umat manusia bahwa beliau mengajarkan dan membagikan ilmu Allah dengan cara atau metode tertentu. 


\section{METODOLOGI PENELITIAN}

Adapun metode yang digunakan adalah library research atau studi kepustakaan. Dalam metode ini penulis mempelajari dan mengumpulkan data tertulis dengan cara menelaah al-Qur'an, tafsir, buku buku dan teori-teori yang ada hubungannya dengan masalah yang diteliti.

Adapun teknik pengolahan data diperoleh melalui kajian buku buku kemudian dianalisis melalui metode deduktif yaitu menganalisis data yang berpegang pada kaidahkaidah umum untuk menentukan kesimpulan yang bersifat khsusus.

\section{HASIL KAJIAN DAN PEMBAHASAN}

Keteladanan dalam pendidikan adalah cara yang paling efektif dan cukup berhasil dalam mempersiapkan anak dari segi akhlak, membentuk mental dan sosialnya. Hal ini dikarenakan pendidik adalah panutan atau idola dalam pandangan anak dan contoh yang baik di mata anak. Anak akan mengikuti tingkah laku pendidiknya, meniru akhlaknya, baik disadari maupun tidak. Bahkan sebuah bentuk perkataan dan perbuatan pendidik akan tetap ada dalam diri anak dan menjadi bagian dari persepsinya. (Abdullah Nashih 'Ulwan, pendidikan dalam islam: 603)

Metode ini merupakan yang sangat berpengaruh terhadap baik buruknya anak. Karena jika seorang pendidik adalah orang yang jujur dan terpercaya, maka anakpun akan tumbuh dalam kejujuran dan sikap amanah pula. Namun, jika pendidik adalah seorang yang pendusta dan khianat maka anak juga akan tumbuh dalam kebiasaan dusta dan tidak bisa dipercaya.

Setiap anak memiliki fitrahnya (potensi) masing-masing yang dapat menjadi baik, namun sebesar apapun potensi itu, anak tidak akan begitu saja mengikuti prinsipprinsip kebaikan selama ia belum melihat pendidiknya memeprlihatkan akhlak yang baik dan mulia serta memberikan contoh yang baik.

Sangat mudah bagi pendidik memberikan satu pelajaran bagi anak, namun sangat sulit bagi anak untuk mengikutinya ketika ia melihat orang yang memberikan pelajaran tersebut tidak mempraktekan apa yang dajarkannya.

Oleh karena itu, Allah telah mengutus seorang Rosul untuk menyampaikan dakwah kepada umat, dan seorang Rosul itu haruslah memiliki sifat yang sempurna, jiwa yang bersih, akhlak yang mulia dan akal yang tinggi. Sehingga orang-orang dapat menjadikannya rujukan, menuruti, belajar darinya, dan mencontohnya dalam kemuliaan dan ketinggian akhlak.

Hal ini terdapat pada Q.S al Ahzab (33): 21.

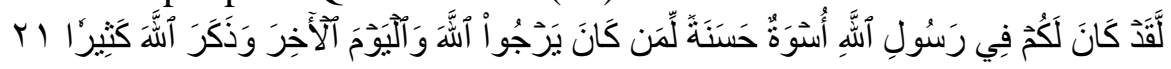

"Sesungguhnya telah ada pada (diri) Rasulullah itu suri teladan yang

baik bagimu (yaitu) bagi orang yang mengharap (rahmat) Allah dan

(kedatangan) hari kiamat dan dia banyak menyebut Allah"

\section{a. Tentang ayat.}

Setelah Allah menyebutkan perang ahzab (khandaq) dan kedudukan orang munafik yang tidak punya keteguhan hati pada perang itu, yaitu tidak takut berperang 
dan mengurangi semangat orang-orang yang ikut berperang menjadi ragu, maka Allah memerintahkan kepada orang-orang mukmin pada ayat-ayat berikut untuk mengikuti Nabi Muahammad SAW dalam bersabar, teguh, berkorban, dan berjihad.

\section{b. Tafsir ayat}

"Sesungguhnya telah ada pada (diri) Rasulullah itu suri teladan yang baik bagimu.." hai orang-orang yang beriman, sungguh pada Rosul yang mulia itu ada panutan yang baik bagi kalian. Kalian mengikutinya dalam keikhlasannya, jihad dan sabarnya. Beliaulah percontohan tertinggi yang harus diikuti dalam seluruh aspek kehidupan. Karena beliau tidak pernah berkata maupun berbuat berdasarkan nafsu, namun berdasarkan wahyu dalam al Qur'an, oleh kerena itu kalian harus selalu mengikuti metode dan jalannya. (Syaikh Muhammad Ali ash Shabuni, Shafwatut Tafasir: 232)

Ayat yang mulia ini adalah pokok yang agung tentang mencontoh Rasul dalam berbagai perkataan, perbuatan, dan perilakunya. Untuk itu Allah memerintahkan manusia untuk mensuritauladani Rasul pada hari Ahzab dalam kesabaran, keteguhan, kepahlawanan, perjuangan, dan kesabaran dalam menanti pertolongan dari Allah. (Ibnu Katsir, 461)

Ada beberapa contoh teladan beliau dalam akhlak yang luhur, seperti kedermawanan dan zuhud beliau, tawadhu dan pemaaf beliau, atau keberanian beliau dalam bersiasat dengan cara yang cerdik dan teguh memegang prinsip.

Berikut ini beberapa contoh tuntunan Rasul dalam mengingatkan kepada pendidik untuk senantiasa memberikan contoh teladan yang baik.

1. Diriwayatkan dari Abdullah bin Amir r.a, "pada suatu hari ibuku memanggilku dan Rasulullah saw saat itu sedang duduk di rumah kami. Ibuku berkata, "wahai Abdullah, kemari aku ingin memberimu sesuatu. Lalu Rasulullah saw pun berkata, "apa yang hendak engkau berikan? Ibuku menjawab, "aku ingin memberinya kurma". Lalu beliau bersabda, "seandainya engkau tidak memberikan apa-apa, maka dicatat satu kebohongan untukmu." (HR. Abu Daud dan al Baihaqi). Dalam hadist di atas menunjukkan bahwa Rasul sangat menganjurkan kepada pendidik untuk senantiasa berperilaku jujur kepada anak agar menjadi teladan yang baik bagi mereka.

2. Rasulullah saw bersabda, "wahai Basyir, apakah engkau memiliki anak selain ini?”. Ia menjawab, “ia”. Beliau bersabda, “apakah semuanya engkau beri hadiah seperti ini?" Ia menjawab, "Tidak". Kemudian beliau bersabda, "Kalau begitu janganlah engkau persaksikan kepadaku, karena aku tidak ingin menjadi saksi ketidakadilan”. (HR. Bukhari dan Muslim). Tuntunan beliau dalam hadist di atas merupakan anjuran beliau kepada pendidik untuk menunjukkan keadilan kepada anak agar menjadi teladan yang baik bagi mereka.

3. Diriwayatkan bahwa ketika Rasulullah saw sedang shalat mengimami orangorang tiba-tiba datanglah al Husain. Lalu ia naik ke atas leher beliau saat beliau sedang sujud. Beliaupun memeperlama sujudnya bersama orang-orang, sehingga kami mengira telah terjadi sesuatu pada beliau, kemudian beliau 
bersabda,"Anakku ini menaikiku, maka aku tidak ingin tergesa-gesa sampai ia merasa puas." (HR. An-Nasa'i dan al Hakim). (Abdullah Nashih 'Ulwan, pendidikan dalam islam: 618). Hal ini menunjukkan bahwa seorang pendidik harus memilik sifat kasih sayang, agar terjalin hubungan baik yang sesuai dengan syariat Islam tentunya.

\section{Mendidik Dengan Kebiasaan.}

Telah ditetapkan dalam syariat Islam bahwa anak semenjak lahir sudah diciptakan dan diberikan ketauhidan yang murni, agama yang lurus, dan iman kepada Allah. Sebagaimana firman Allah swt dalam Q.S. ar-Ruum: 30.

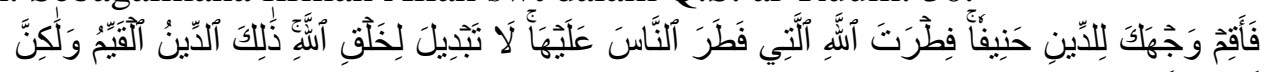

"Maka hadapkanlah wajahmu dengan lurus kepada agama Allah; (tetaplah atas) fitrah Allah yang telah menciptakan manusia menurut fitrah itu. Tidak ada peubahan pada fitrah Allah. (Itulah) agama yang lurus; tetapi kebanyakan manusia tidak mengetahui."

\section{a. Tentang Ayat}

Ayat ini merupakan suatu pengarahan untuk menghadapkan wajah kepada agama yang lurus yang datang pada waktunya dan pada tempatnya, setelah perjalananperjalanan di alam semesta dan panoramanya, serta kedalaman diri dan fitrahnya. Kemudian ayat ini juga merupakan perintah untuk menghadap kepada Allah degan lurus. Agama ini adalah penjaga dari hawa nafsu yang terpecah pecah yang tidak berdiri di atas kebenaran, dan tidak berdasarkan diri kepada ilmu pengatahuan.

\section{b. Tafsir Ayat}

Ayat ini merupakan perintah untuk memeperkokoh pandangan (prinsip hidup) dan mengistiqomahkan segala sesuatu di atas agama yang disyari'atkan Allah kepada umat manusia, berupa kesucian ajaran Ibarhim a.s yang Allah bimbing kamu kepadanya dan disempurnakan Allah agama itu untukmu dengan sangat sempurna. Di samping itu hendaklah engkau konsekuen terhadap fitrah lurusmu yang difitrahkan Allah atas makhluk-Nya. Karena Allah telah memfitrahkan makhluk-Nya untuk mengenal dan mengesakan-Nya yang tidak ada Ilah (yang haq) selain-Nya. (Ibnu Katsir: 371).

Sedangkan menurut Sayyid Quthub dalam Tafsirnya, menjelaskan bahwa ayat ini merupakan sebuah pengarahan untuk menghadapkan wajah kepada agama yang lurus yang datang pada waktunya dan pada tempatnya. Menghadaplah kepada-Nya dengan lurus. Agama ini adalah penjaga dari hawa nafsu yang terpecah-pecah yang tidak berdiri di atas kebenaran, dan tidak mendasarkan diri kepada ilmu pengetahuan. Akan tetapi semata mengikuti syahwat dan dorongan diri tanpa batasan dan tanpa petunjuk. Hadapkanlah wajahmu kepada agama yang lurus, agama yang disyariatkan oleh Allah kepada seluruh manusia dan isinya. Serta hadapkanlah wajahmu kepada agama yang lurus, dengan cara memalingkan wajah dari semua yang selainnya. (Sayyid Quthub, Tafsir Fi Zhilalil Qur'an: 143). 


\section{c. Penjelasan Ayat Hubungannya dengan Pendidikan}

Telah ditetapkan dalam syariat Islam bawha setiap anak semenjak lahir sudah diciptakan dalam keadaan bertauhid yang murni, agama yanglurus, dan iman kepada Allah. Dari sini kita dapat mulai melakukan pembiasaan dan pendisplinan mengambil perannya, dalam pertumbuhan anak dan menguatkan tauhid yang murni, akhlak yang mulia, jiwa yang agung dan etika syariat yang lurus. Oleh karena itu, dapat dipastikan bahwa seorang anak akan menjadi pribadi yang shalih apabila ada dua faktor yang mendukungnya, yaitu faktor pendidikan Islam yang luhur dan faktor lingkungan yang kondusif. (Abdullah Nashih 'Ulwan, Pendidikan dalam Islam: 625)

Mengenai fakor Pendidikan Islam ini, Rasulullah telah menjelaskannya di dalam sebuah hadist. Yang artinya, "Tidak ada hadiah yang diberikan seorang ayah kepada anaknya yang lebih baik dari pada pendidikan yang baik". (HR. AtTirmidzi) .

Sedangkan mengenai faktor lingkungan yang kondusif pun dijelaskan dalam sebuah hadist pula, yang artinya, "Setiap bayi yang dilahirkan dalam keadaan fitrah, maka kedua orangtuanya lah yang menjadikan Yahudi, Nasrani ataupun Majusi". (HR. Bukhori). Dapat dipahami bahwa jika seorang anak memilik orang tua yang shalih dan shalihah, mereka akan senantiasa mengajarkan prnisip-prinsip iman dan Islam sehingga anak akan tumbuh dengan akidah keimanan dan keislaman yang kuat.

Terdapat hadist lain yang menjelaskan tentang lingkungan kondusif, hadist yang aritnya, "Seseorang itu tergantung agama temannya. Maka perhatikanlah oleh salah seorang dari kalian, dengan siapa seseorang itu berteman". (HR.At Tirmidzi). Seorang teman pun akan mempengaruhi seseorang apabila temannya itu shalih, maka dapat dipastikan ia pun akan shalih, karena seseorang akan meniru kebiasaan temannya.

Ketika kemampuan anak dan sifat fitrahnya dalam menerima pelajaran dan pembiasaan lebih besar dibandingakn usianya, maka pendidik itu harus lebih memfokuskan untuk memberi ajaran kebaikan kepad anak dan membiasakannya sejak ia mulai memahami kehidupan.

Mengenai hal ini, Abdullah Nashih memberikan tips kepada pendidik dalam mengajarkan pembiasaan kepada anak, sehingga anak memiliki pemahaman yang benar.

1. Rasulullah saw memerintahkan kepada pendidik untuk mengajarkan kalimat laa ilaa ha illallah (tiada tuhan selain Allah) kepada anak-anak mereka. Sebagaimana dalam hadits yang diriwayatkan al Hakim dari Ibnu Abbas r.a bahwa Rasulullah saw bersabda, "Bukalah untuk anak-anak kalian kalimat pertamanya dengan Laa ilaa ha illallah.” Hal ini akan membiasakan anak untuk mengimani dan meyakini dengan kedalaman hati dan perasaanya bahwa tidak ada pencipta dan tidak ada Tuhan selain 
yang hak kecuali Allah dan memperlihatkan tanda-tanda penciptaan yang dapat dilihat oleh anaks secara langsung.

2. Rasulullah saw memerintahkan kepada para pendidik untuk menginstruksikan shalat kepada anak-anak mereka saat berusia 7 tahun. Sebagaimana hadist yang diriwayatkan oleh al Hakim dan Abu Dawud, dari Abdullah bin 'Amr bin Ash. Bahwa Rasulullah saw bersabda,"Perintahkanlah kepada anak-anak kalian untuk shalat saat mereka berusia 7 tahun, dan pukullah mereka (ketika meninggalkannya) pada saat usia 10 tahun, serta pisahkan tempat tidur mereka." Cara ini akan membiasakan anak untuk melaksanakan shalat dengan tekun dan melaksanakannya di masjid secara berjamaah, sehingga shalat ini menjadi akhlak dan kebiasaannya.

3. Rasulullah saw memerintahkan kepada para pendidik untuk senantiasa mengajarkan tentang halal-haram. Sebagaimana dalam hadist yang diriwayatkan oleh Ibnu Jarir dan Ibnu Mundzir dari Ibnu Abbas r.a bahwa beliau bersabda,"Perintahlah anak-anak kalian untuk melaksanakan perintah-perintah dan menjauhi segala larangan, karena itu akan mencegah untuk mereka dan kali dari api neraka." Hal ini akan melatih kebiasaan anak untuk melaksanakan perintah Allah dan menjauhi larangannya.

4. Rasulullah saw memerintahkan kepada para pendidik untuk menginstruksikan kepada anak-anak mereka untuk saling mencintai Nabinya, keluarga, para sahabatnya, serta membaca al Qur'an. Sebagaimana dalam hadits yang diriwayatkan oleh ath-Tabhrani dari Ali r.a, bahwa Rasulullah saw bersabda,'Didiklah anak-anak kalian dengan tiga perkara: mencintai nabi kalian, mencintai keluarganya, dan membaca al Qur'an”. Pendidik sangat bisa mengumpulkan anak-anaknya dan membacakannya kepada mereka kisah-kisah sejarah para Nabi, keluarga, dan shabat nabi terdahulu. (Abdullah Nashih 'Ulwan, Pendidikan dalam Islam: 635-637)

\section{Mendidik dengan Nasihat}

Satu lagi metode pendidikan dalam Islam yang efektif dalam membentuk keimanan anak, akhlak, mental dan sosialnya, adalah metode mendidik dengan nasihat. Hal ini dikarenakan nasihat memiliki pengaruh yang sangat besar untuk membuat anak mengerti hakikat sesuatu dan memberinya kesadaran prinsip-prinsip Islam.

Metode ini pun ada dalam al Qur'an surah Luqman ayat 13.

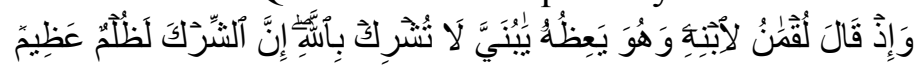

"Dan (ingatlah) ketika Luqman berkata kepada anaknya, di waktu ia memberi pelajaran kepadanya: "Hai anakku, janganlah kamu mempersekutukan Allah, sesungguhnya mempersekutukan (Allah) adalah benar-benar kezaliman yang besar" 


\section{a. Tentang Ayat}

Ayat ini menjelaskan tentang seseorang ayah yang memberikan nasihat terpenting dalam hidup, yaitu mengingatkan agar tidak pernah menyekutukan Allah, dengan berbuat syirik. Dan luqman pun melarang dari berbuat syirik, dan ia memberi alasan atas larangan tersebut bahwa perbuatan syirik itu merupakan kezhaliman yang sangat besar.

\section{b. Tafsir Ayat}

Menurut Ibnu Katsir, Ayat ini mengabarkan tentang wasiat Luqman kepada puteranya, yaitu Luqman bin 'Unaqa bin Sadun, sedangkan nama puteranya adalah Tsaran, menurut satu pendapat yang diceriatakan oleh as Shuhaily. Allah telah menyebutkannya dengan sebaik-baiknya sebutan dan diberikannya dia hikmah. Dia memberikan wasiat kepada puteranya yang merupakan orang yang paling dikasihi dan dicintainya, dan ini hakikat pemberian seorang anak. Untuk itu, pertama-tama ia memberikan wasiat untuk selalu beribadah kepada Allah Ta'ala Yang MahaEsa yang tidak ada sekutu bagi-Nya. Kemudia ia memperingatkan pula, sesungguhnya mempersekutukan Allah adalah kezhaliman yang sangat besar. (Ibnu Katsir: 400-401)

Orang tua sangat menginginkan anaknya menjadi ahli kebaikan, da orang tua mungkin hanya sebagai teladan dan penasihat bagi anaknya. Seperti Luqman melarang kepada anaknya berbuat syirik, dan dia memberikan alasan atas larangan itu, bahwa kemusyrikan adalah kezaliman yang sangat besar. (Sayyid Quthub, Tafsir Fi Zhilalil Qur'an: 174) .

Dalam nasihat dari seorang ayah kepada anaknya, al Qur'an memaparkan hubungan antara kedua orang tua dengan anak-anaknya. Ia menggambarkan hubungan tersebut dalam gambaran kasih sayang dan kelembutan. Kelembutan ini akan timbul apabila dalam suatu keluarga memiliki aqidah dan keimanan yang sangat kuat terhadap Allah Ta'ala.

\section{c. Penjelasan Ayat Hubungannya dengan Pendidikan}

Al Qur'an memiliki gaya dan metode yang bermacam-macam dalam berdakwah, mengingatkan tentang Allah, memberikan nasihat dan bimbingan. Semua itu digunakan melalui lisan para nabi dan rosul dan diulang-ulang oleh para pengikutnya. Semua sepakat bahwa nasihat yang tulus dan ikhlas akan sangat berpengaruh terhadap hati dan akalnya.

Dalam al Qur'an sendiri, nasihat digunakan sebagai salah satu metode pendekatan dalam mendidik. Terkadang nasihat dalam bentuk ketakwaan, peringatan, anjuran untuk mengikuti nasihat, untuk mengikuti jalan yang lurus, memberikan semangat atau terkadang menggunakan ancaman sebagai nasihat.

Ada beberapa cara al Qur'an menyampaikan nasihat dengan gaya bahasa, di antaranya:

1. Seruan persuasif yang disertai pengambilan hati dan pengingkaran.

Gaya bahasa ini memiliki sugesti yang kuat terhadap perasaan dan hati. Seruan pengingkaran atau pengambilan hati ini masih sangat jelas tampak pada saat al Qur'an 
mengajak bicara kepada hati manusia dan akalnya dengan perbedaan karakter, jenis, dan tingkat sosial mereka.

2. Gaya bahasa kisah yang disertai pelajaran dan nasihat

Gaya bahasa ini memiliki pengaruh terhadap jiwa, kesan terhadap pikiran, dan argumen yang logis. Al Qur'an menggunakan gaya bahasa ini dalam beberapa ayat, terutama ayat yang mengisahkan

3. Pengarahan al Qur'an yang mengandung pesan dan nasihat.

Al Qur'an memiliki pengaruh yang kuat terhadap hati seseorang yang mendengarkan lantunannya. Hal ini akan menjadikan hati pendengarnya akan merasa khusyuk, fokus terhadap ayat yang dibacakan dan ruhnya tergerak untuk melakukan kebaikan yang sesuai dengan isi al Qur'an. Sehingga melalui bacaan ayat-ayat itu ia akan terdorong untuk melaksanakan nasihat-nasihat yang terkandung di dalamnya, melakukan pesan-pesannya, menjalankan perintah-perintahnya dan menjauhi larangannya.

Rasulullah telah memberikan perhatian yang sangat besar terhadap penyampaian nasihat dan mengarahkan para pendidik dan orang yang berdakwah untuk senantiasa menyampaikan nasihat. Selain itu, beliau juga mengajak muslim dalam kehidupannya masing-masing menjadi orang yang menyampaikan dakwah Allah di manapun mereka berada.

Ada beberapa pengarahan penting yang Rasulullah berikan dalam menyampaikan nasihat dan dakwah. Tamim bis Aus ad Dari r.a meriwayatkan bahwa Nabi saw bersabda: "agama itu adalah nasihat." Kami bertanya, "Karena siapa?" beliau menjawab, "Karena Allah, kitab-Nya, Rasul-Nya, pemimpin kaum muslimin, dan orang umum mereka.” (HR.Muslim). Oleh karena itu, seorang pendidik haruslah menjadikan metode dan pendekatan itu bersumber dari al Qur'an dan as Sunnah. (Abdullah Nashih 'Ulwan, pendidikan dalam islam:

\section{Mendidik dengan Perhatian Atau Pengawasan}

Maksud dari mendidik dengan cara memberikan perhatian adalah mengikuti perkembangan anak dan mengawasinya dalam pembentukan akidah, akhlak, mental, dan sosialnya, begitupun dengan perkembangan fisik dan intelektualnya. Oleh karena itu, metode dengan cara ini merupakan metode yang sangat kuat untuk membentuk manusia yang seimbang, yaitu

1. Sanggup memberikan semua haknya sesuai dengan porsinya masing-masing

2. Sanggup mengemban semua tanggung jawab yang harus dipikulnya

3. Sanggup melakukan semua kewajibannya

4. Sanggup membangun pondasi keimanan yang kokoh.

Metode ini terdapat pada al Qur'an Surah at Tahrim ayat 6.

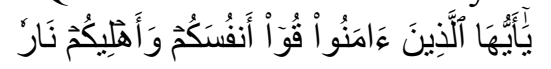

"Hai orang-orang yang beriman, peliharalah dirimu dan keluargamu dari api neraka..." 


\section{a. Tentang Ayat}

Ayat ini menjelaskan tetang perintah kepada orang tua dan pendidik lainnya agar selalu memperhatikan dan mengawasi anak-anak mereka di semua aspek kehidupan dan pendidikannya. Karena dengan menjaga dan memperhatikan anak-anak, akan selalu terawasi segala kegiatan mereka setiap hari, hal inilah yang akan menjauhkan kita dan anak-anak kita dari api neraka.

\section{b. Tafsir Ayat}

Dalam tafsir Ibu Kasir, Mengenai Firman Allah Ta'ala di atas, Mujahid mengatakan,'Bertakwalah kepada Allah dan berpesanlah kepada keluarga kalian untuk bertakwa kepada Allah". Sedangkan Qatadah mengemukakan,"Yakni hendaklah engkau menyuruh mereka berbuat taat kepada Allah dan mencegah mereka berbaut durhaka kepada Allah. Dan hendaklah engkau menjalankan perintah Allah kepada mereka dan perintahkan mereka untuk menjalankannya, serta membantu mereka dalam menjalankannya. Jika engkau melihat mereka berbuat maksiat kepada Allah, peringatkan dan cegahlah mereka." Demikian pula yang dikemukakan oleh adh-Dahhak dan Muqatil bin hayyan, mereka mengatakan bahwa setiap muslim berkewajiban mengajari keluarganya, termasuk kerabat dan budaknya, berbagai hal berkenaan dengan hal-hal yang diwajibkan Allah Ta'ala kepada mereka dan apa yang dilarang-Nya."(Ibnu Kasir: 229)

\section{c. Penjelasan Ayat Hubungannya Dengan Pendidikan}

Semua muslim telah sepakat, bahwa perhatian dan pengawasan pada diri pendidik merupakan unsur pendidikan yang paling utama. Karena dengan cara seperti itu, anak akan selalu ada dalam pantauan pendidik, mulai dari gerak geriknya, perkataan, perbuatan, sampai orientasi dan kecenderungannya. Jika pendidik melihat anak berbuat kejelekan, pendidik harus langsung melarang dan memperingatkannya serta menjelaskan akibat buruk dari perbuatan jelek tersebut. Akan tetapi sebaliknya, jika pendidik lalai atau pura-pura tidak melihat keadaan anak, maka dapat dipastikan anak akan mengarah kepada penyimpangan.

Guru pertama kita, Rasulullah saw telah memberikan tauladan kepada kita sebagai umatnya, dalam memperhatikan dan mengawasi anak, belia contohkan kepada para sahabat. Beliau senantiasa menyanyakan keadaan mereka, mengawasi perilaku mereka, memberi peringatan ketika mereka lalai, mendukungnya ketika mereka berbuat kebaikan, mengasihi mereka yang miskin, mendidik mereka yang masih kecil, menghargai yang lebih tua, dan mengajarkan sesuatu kepada mereka yang belum mengerti akan ilmu. (Abdullah Nashih 'Ulwan, pendidikan dalam islam: 669). Berikut ini beberapa contoh perhatian dan pengawasan Rasulullah saw:

\section{Perhatian Rasulullah saw terhadap Pendidikan Sosial.}

Diriwayatkan dari Abu Sa'id Al-Khudri Ra bahwa rasulullah SAW bersabda :"Jangaanlah kalian duduk dijalan." Maka mereka berkata, "Kami terpaksa, karena itu tempat kami berkumpul untuk berbincang-bincang." Beliau pun berkata, "Apabila kalian tidak bisa kecuali hanya untuk duduk disana, maka berikanlah pada jalan itu haknya." Mereka bertanya " Apakah hak jalan itu ?" Nabi SAW bersabda, 
"Tundukanlah pandangan, menahan diri dari mengganggu orang lain, menjawab salam, memerintah kebaikan, dan melarang kemungkaran." (HR. Al-Bukhari dan Muslim).

\section{Perhatian Rasulullah SAW dalam memberi peringatan dari yang haram.}

Diriwayatkan dari Ibnu Abbas Ra bahwa rasulullah SAW melihat cincin pada jari seseorang. Beliau lantas melepaskan dan meletakkannya sembari bersabda : "Seseorang dari kalian ada yang sengaja menuju kepada bara api dari neraka, maka ia menjadikannya dalam tangannya."

Kemudian setelah Rasulullah SAW pergi, kepada orang yang memiliki cincin itu dikatakan, "Ambillah cincinmu. Manfaatkanlah ia (untuk keperluan lain)." Orang itu menjawab, "Tidak, demi Allah, aku tidak akan mengambil cincin ini selamanya. Bukankah ia telah dilemparkan oleh Rasulullah SAW ?" (HR. Muslim).

\section{Perhatian Rasulullah SAW dalam Mendidik Anak.}

Umar bin Abu Salamah Ra berkata, "Ketika masih kecil. Aku dibawah pengasuhan Rasulullah Saw. tanganku pernah bergerak (kesana kemari) di dalam piring besar, maka beliau berkata kepadaku:"Wahai anak, bacalah Basmallah, makanlah dengan tangan kananmu, dan makanlah apa yang dekat denganmu”.(HR. Al-Bukhari dan Muslim)

\section{Perhatian Rasulullah SAW Dalam Membimbing Orang Dewasa.}

Abdullah bin 'Amir Ra berkata "Pada suatu hari, ibuku memanggilku dan Rasulullah saw saat itu sedang duduk dirumah kami. Ibuku berkata, "Wahai Abdullah, kemari. Aku ingin memberimu sesuatu." Lalu rasulullah Saw berkata, "Apa yang hendak engkau berikan ?" Ibuku menjawab, "Aku ingin memberinya kurma." Beliau bersabda:"Seandainya engkau tidak memberinya apa-apa, maka dicatat satu kebohongan untukmu.'(HR. Abu Dawud dan Al-Baihaqi)

\section{Perhatian Rasulullah SAW Terhadap Pendidikan Akhlak.}

Abu Barkah meriwayatkan, "Seseorang memuji seseorang di hadapan Nabi Saw. Maka beliau bersabda:“Celakalah engkau, engkau telah memotong leher sahabatmu (beliau mengatakan berkali-kali). Barang siapa yang harus memuji saudaranya maka katakanlah, 'Aku mengira ia begini dan begitu,' jika ia melihat keadaan (orang yang di puji itu ) demikian, dan Allah lah yang mencukupkan dirinya, dan tidaklah menyucikan seseorangpun di hadapan Allah.” (HR. Al-Bukhari dan Muslim)

\section{Perhatian Rasulullah SAW Terhadap Pendidikan Mental.}

Diriwayatkan dari An-Nu'man bin Basyir Ra bahwa ayahnya membawanya mendatangi Rasulullah saw lalu ia berkata, "Aku memberi hadiah anakku ini seorang budak milikmu.:” Apakah setiap anak engkau beri hadiah sepertinya ?” ia menjawab, "tidak". Lalu beliau bersabda, “Maka ambillah kembali.” (HR. Al-Bukhari dan Muslim)

\section{Perhatian Rasulullah SAW Terhadap Pendidikan Jasmani.}

Ketika Rasulullah saw melihat seseorang yang minum sekaligus seperti unta, beliau bersabda,“ janganlah kalian minum sekaligus seperti minumnya unta. Akan tetapi, minumlah dua kali dua kali dan tiga kali tiga kali. Dan sebutlah nama Allah jika kalian minum, dan ucapkanlah hamdalah jika kalian selesai. (HR. At.Tirmidzi). Diriwayatkan bahwa Nabi Saw melewati para sahabatnya yanmg sedang memanah, 
maka beliau menyemangati mereka dan bersabda kepada mereka: "memanahlah dan aku akan berada bersama kalian".(HR. Al-Bukhari)

\section{Perhatian Rasulullah SAW Terhadap Dakwah Dan Memperlakukan Orang Lain Dengan Kelembutan.}

Diriwayatkan dari Anas bin Malik Ra, "Aku pernah berjalan bersama Nabi Saw. beliau mengenakan kain Najran yang sisinya kasar. Lalu seorang arab gunung menghampirinya dan menariknya dengan keras, sampai aku melihat sisi lehernya berbekas oleh sisi selendangnya karna saking kerasnya beliau ditarik, kemudian orang itu berkata, "Perintahkanlah seseorang untuk memberiku harta Allah yang ada padamu". Beliau memandangnya, lalu tertawa. Kemudian beliau menyuruh untuk memberikannya." (HR. Bukhari dan Muslim). (Abdullah Nashih 'Ulwan, pendidikan dalam islam: 672)

\section{SIMPULAN}

Pendidikan merupakan sarana untuk meningkatkan keimanan dan ketakwaan kepada Allah swt, serta akhlak yang mulia, mencakup etika, moral, budi pekerti, spiritual atau pemahaman dan pengalaman nilai-nilai keagamaan dalam kehidupan sehari-hari. Pendidikan agama kepada anak harus sudah dilakukan dan dibiasakan sejak janin masih ada dalam kandungan.

Pola pendidikan agama Islam yang dipraktekan oleh orang tua ataupun pendidik di sekolah dengan metode keteladanan, kebiasaan, nasihat dan hukuman. Metodemetode tersebut yang dipraktikan tidak bisa berdiri sendiri, tetapi saling mendukung satu sama lain dan digunakan sesuai dengan situasi dan kondisi yang ada.

\section{DAFTAR PUSTAKA}

Nashih Ulwan, Abdullah, Pendidikan Anak Dalam Islam, Depok, Fathan Prima Media, 2016.

Ali Ash-Shabuni, Syaikh Muhammad, Shafwatut Tafasir: Tafsir-Tafsir Pilihan, Jakarta, Pustaka Al-Kautsar, 2011.

Ishaq al-Sheikh, Muhammad bin Abdurahman Abdullah bin Muhammad, Lubaabut Tafsir Min Ibni Katsiir: Tafsir Ibnu Katsir, Kairo, Muassasah Daar al-Hilaal, 1994.

Quthb, Sayyid bin Ibrahim Husain, Tafsir fi Zhilalil Qur'an, Kairo Mesir, Darusy Sruruq, 1992. 